\title{
Linking Supply Chain Management and Food Security: A Concept of Building Sustainable Competitive Advantage of Agribusiness in Developing Economies
}

\author{
Joni Murti Mulyo Aji, ${ }^{1, *}$ \\ ${ }^{1}$ Department of Agribusiness, Faculty of Agriculture, University of Jember
}

\begin{abstract}
Theoretically, improved food security can be achieved through (a) increased availability - by extending staple food production area, higher productivity, good post harvesting practices; (b) enhanced access - as a result of more stable prices, improved farmer income, or even rural income; and (c) increased stability - through improved and sustained competitive advantage of the member firms, which eventually contribute to sustainable industry including in agriculture. Nonetheless, there has been a limited study linking the concept of food security and the necessity of managing competitive advantage of the agricultural supply chains. This paper links the theoretical foundations of supply chain management the concept of food security policy. Through a review of literature, a concept of how sustainable competitive advantage can be achieved through supply chain management, which in a development context, can improve food security by bringing together the concepts of food availability as well as improved people access to sufficient food is further explored.
\end{abstract}

\section{INTRODUCTION}

Food insecurity is a problem for most developing countries. To achieve food security, traditionally, the solutions are directed to a focus of improving production to build national targets of self-sufficiency level, coordinating world food stocks and implementing stabilisation policies of imports [1], [2]. Especially in developing countries, food self-sufficiency commonly has been set up as a national commitment. It is directed in national planning and achieved through agricultural policies and programs to meet national level targets of staple food production. While many developing countries associate food security with food selfsufficiency, widespread evidence shows that hunger may still coexist with the availability of abundant food supplies. Especially in the era of Industry 4.0, a thinking shift to expand analysis of food security moving from a narrow focus merely on food supplies, to a wider range that includes an access dimension of households and individuals is indeed necessary. Empirical evidence demonstrated that access to food by individuals is often the greater constraint than the availability of the food itself. Food access often depends on individuals' income, which is also influenced by their access to resources, markets, technology, social networks, and government support through food transfer programs or subsidy.

While improved food security can be achieved through increased availability - by extending staple food production area, improved productivity, better post harvesting practices; enhanced access - as a result of more stable prices, improved farmer income, or even rural income; and increased stability - through improved and sustained competitive advantage of the member firms [3], which eventually contribute to sustainable industry including in agriculture, study linking the concept of food security and the necessity of improving competitive advantage through agricultural supply chain management is limited. This paper links the theoretical foundations of supply chain management and the concept of food security as an essential government policy. Through a review of literature, this paper aims to show how supply chain management creates a sustainable competitive advantage, which in a development context, can improve food security by sustaining food availability, maintaining stability of food supply, and improving people's access to food. This kind of approach is expected to create better food security as it builds more sustainable competitive advantage of agribusiness in developing economies than, for example, the use of traditional price policy.

\section{THEORETICAL FOUNDATION OF SUPPLY CHAIN MANAGEMENT}

The APICS dictionary defines the supply chain as all processes of producing and delivering products, from

Corresponding author: joni.faperta@unej.ac.id 
raw materials to consumptions in the end. A supply chain links across suppliers to the ultimate-users as well as the functions within and outside a company that makes value of products and provides services to customers [4]. A supply chain is also the network of organisations that are involved in the various activities and processes through their linkages from upstream to downstream that create value embedded in goods and services delivered to the customer [5]. The term 'supply chain' is frequently described as an extension of a marketing channel. However, unlike the marketing channel, a supply chain emphasises inter-firm communication, the management of lesser inventories, lead time reduction, customer orientation, product as well as process re-engineering, and long-term relationships between channel members [6]. Other terms like 'value chain' or 'demand chain' are often used instead of 'supply chain,' suggesting that a supply chain is an integrated process for producing value for the end consumer [7].

A supply chain consists of physical, financial and information flows. The physical dimension of a supply chain is basically the product flow features of the chain. This dimension includes a number of processes or activities that create the value of products or services for the satisfaction of customers. It involves transportation and logistics that are necessary for delivering products or services. The physical flow also involves a number of business exchange relationships between the exchange partners, i.e., buyers and suppliers.

The financial dimension consists of a series of money exchange relationships between participants in the chain, which is reflected by the cash flow throughout the processes across the supply chain members [8]. Another element of this dimension is financial performance information sharing across the chain, i.e., among members and in any stages of the relationships.

The information flow in the supply chain involves the market signalling amongst the members. Important elements of this dimension are information accuracy, including whether messages are signals or noise, the cost of messaging, the strength of these messages, the speed of delivering and receiving messages, and the sincerity to sharing among participants rather than holding critical information itself [9].

Supply chain management (SCM) is defined as an integrative concept to manage the flow of goods and/or services in a whole distribution chain from supplier to the end users [10]. The aim of managing the supply chain is to synchronise the buyers' needs of a product including the flow of the product from their suppliers in order to create a balance between those often seen as the contradictory goals of customer service, efficient stock system, and low costs per unit [11].

SCM encompasses a number of firms within a distribution chain that enter a long term relationship based on trust and commitment [12]. More importantly, supply chain management uses 'a systems approach' to looking at the whole supply chain as a single entity rather than as a set of fragmented parts. In other words, the supply chain management philosophy has broadened the concept of partnerships into a multi-firm's effort to manage the overall flow of products from the producer ahead to the supplier until the end customer. Supply chain management also seeks to synchronise and converge intra-firm and inter-firm operational and strategic capabilities into a unified whole [13]-[15].

Supply chain management benefits all participants in the chain as it seeks to overcome the barriers which exist in each of the links within the chain in order to accomplish higher levels of service. It seek to substantially reduce costs by developing a relationship of mutual benefit, defining the organisational structures, and sustaining long term relationships between buyer and supplier, which have been traditionally identified as adversarial [16]. Improvement in supply chain management refers to improving the competitiveness of the whole supply chain, a situation in which every party involved is at least as well off, and one party is better off than before [17].

In the supply chain management concept, to achieve competitive advantage, all strategic business units should be willing to carry out value adding activities in their business processes [18]. However, the structure of activities or processes between and within companies is also crucial for the formation of a superior competitive advantage. In other words, the structure of collaboration within and between the parties involved in a supply chain is critical to value creation in the chain, and this, in turn, will affect the competitiveness of the chain itself. By working collaboratively through supply chain management, all chain members benefit from: a common focus on value creation, long term competitive sustainability; improved information accuracy; an ability to leverage each other's skills; improved efficiency through cost reduction; and more equitable value sharing [19].

\subsection{The Antecedents of Supply Chain Management}

The antecedents of supply chain management are the factors that potentially either enhance or inhibit SCM being implemented. It is also argued that relationship marketing factors, particularly trust, commitment, and interdependence combined with organisational compatibility, visions, key processes, leader and top management support, are the antecedents of SCM [14]. Considering the nature of supply chains in a developing country which is normally characterised by multiple layers, this paper specifically points out the importance of power dependence and product differentiation [8] as the antecedents of supply chain management.

Relationship marketing includes all marketing activities directed towards initiating, developing, and maintaining the exchange relationships [20]. Relationship marketing can also be viewed as the development, maintenance, and conservation of networks and interactive relationships between the supplier and the buyer, often with long term implications. Consequently, marketing becomes, first and foremost, relationship marketing. Relationship marketing is established when marketing is seen as 
embodying relationships, interaction and networks [21][23].

The establishment of high quality relationships offers advantages to all parties involved in the relationships [24]. By establishing closer relationships, firms may achieve cost reductions through saving search and evaluation costs, reduced transaction costs, and the learning effect from relationship specific scale economies [25]-[27]. However, the greatest advantage arising from relationship marketing, particularly in agrifood systems, is the reduction in uncertainty [25], [28].

Trust is the fundamental determinant of good buyer-supplier relationships [20], [27], [29]-[31]. Trust has been defined as one party's confidence in the other's reliability and integrity [20]. Trust in an exchange relationship is one's willingness to rely on a partner to whom one is confident [32]. However, trust is also a belief that its need will be fulfilled by the actions undertaken by the other party in the future [33]. A trust exists when one party believes that its partner will commit to taking actions that generate positive outcomes and not taking actions that may result in unexpected outcomes [34].

However, as a behavioural intention, trust reflects reliance on a partner, but in so doing, involves some degree of both vulnerability and uncertainty on the part of the trustor. In the absence of vulnerability and uncertainty, trust is not necessary since the outcomes are inconsequential for the trustor [32]. Over reliance on a partner without a concurrent belief about the partner's trustworthiness may end with control and power rather than trust [35].

High levels of trust encourage both firms to focus on the long lasting mutual benefits of the exchange [30]. Firms with long term orientation rely on the relational mechanisms of the market exchange to enhance competitiveness, lower costs and maximise profits. Consequently, mutual trust in a relationship reduces the development of opportunistic intentions and may minimise the need for structural mechanisms of control [29].

Along with trust, commitment is also fundamental to successful relationships. Trust and commitment encourage all parties in an exchange relationship to protect their relationship investments by cooperating with partners. High trust and commitment resist attractive short-term alternatives in favour of expected benefits in the long term [20]. Commitment is the most desirable aspect of relationship marketing. It refers to either an implicit or explicit pledge of relational continuity between the parties involved [36]. Commitment is considered to be closely related to loyalty, mutuality and the forsaking of alternatives. Commitment includes an attitudinal component that signifies an enduring intention by both parties to maintain and enhance a valued long-term relationship [37].

Commitment to relationships goes beyond a simple positive assessment of mutual relationships with the other party, e.g., based on cost-benefits. It involves the adoption of a long-term relationship orientation [33], i.e. a willingness to make short term sacrifices for benefits in the long run [36]. Committed parties are prepared to forgo exploring alternative relationships and rewards over the course of their relationship [38].

The importance of trust and commitment in building long lasting relationships between firms in a marketing channel makes these two factors are considered as two major antecedents of supply chain management. It is further pointed out that trust and commitment lead directly to cooperative behaviours such as cooperation, coordination or collaboration of a supply chain orientation across chain participants to accomplish an integrated supply chain management. Apart from trust and commitment, dependence, leader role (power) and organisational compatibility (norms) are also considered as other antecedents of supply chain management [14].

That notwithstanding, the central tendency of exchange relationships tends to be based on power and dependence. This is particularly evident in developing countries where power and dependence are often observed as crucial factors in exchange relationships [39]-[41]. Exchange relationships often occur in circumstances of asymmetry of the power attributes and therefore, the power automatically becomes a very important factor influencing the relationships [42]. Accordingly, power should be a central thought when dealing with exchange relationships and there should be no barriers for parties seeking to enter more collaborative relationships based on their asymmetric power as long as the parties involved in the relationships can manage their power wisely and understand what the other parties are expecting from the relationships [43].

Theoretically, power takes place when one party is more dominant than other parties. On the other hand, relative dependence increases when a party is increasingly influenced by its partner. Upon closer examination, this suggests that dependence is determined in essence by two factors, i.e., the need for a resource and the availability of alternative sources [44]. In an exchange relationship, the firm's perception of its dependence, relative to its exchange partner is one of the most interest in a channel relationship. Relative dependence refers to the extent to which a firm shall have influence over or be dictated by its partner [34]. Hence, it can be argued that the dependent firm is more likely to be forced to continue the relationship because it seems necessary, given the costs involved in terminating the relationship [33]. Asymmetric dependence can be unstable and less likely to continue in the long run. A long term exchange relationship bounded by dependence forces collaboration rather than cooperation. If a potential relationship with another party is able to perform more favourably in terms of greater equality between partners, then the current relationship may be terminated [30].

It can be concluded that while factors such as trust and commitment are important to relationship marketing, to the development of supply chain management, power-dependence is regarded as the most important factor which potentially guides the relationship management itself. Hence, especially in developing economies where agricultural firms consist of many smallholders who are often dependent on bigger 
parties involved in the marketing channel, it can be proposed that the possibility of using the supply chain management concept will be dependent on the degree to which power-dependent relationships are carefully managed.

Apart from these relational factors, antecedents of supply chain management are also related to the product itself, especially those related to the creation of added value. One important aspect of value creation in a traditional marketing channel is product differentiation. A product is a differentiated product if it has specific attributes that make the product different than those of its competitors. Product differentiation is a source of competitive advantage [45]. Nevertheless, product differentiation also increases a firm's perceived need to move towards closer relationships with partners, thus potentially leading to the establishment of more collaborative supply chain relationships. This is because more differentiated products generally require better communication and improved information accuracy across the chain. Increased complexity in product differentiation requires increased control and collaborative actions which are more easily obtained in more collaborative supply chain management [9]. Product differentiation basically encourages the establishment of collaborative supply chain management. The opportunity to differentiate provides an incentive for the formation of more collaborative partnerships across the chain.

Product differentiation provides an opportunity to create greater value to be shared among participants in a supply chain. This generates an opportunity to establish win-win outcomes in which value arising from joint actions can be shared more equitably across the chain; an ideal condition for building more collaborative and sustainable supply chain management which is often not available in the production of commodities, as the total sum of value tends to be fixed [46]. Product differentiation, on the other hand, often requires raw inputs with a high degree of specificity, which ultimately promotes the establishment of collaborative and more sustainable supply chain management [47].

\subsection{Building Competitive Agri-food Supply Chain: The Role of Government}

In response to a range of economic pressures and increasing levels of competition, agribusiness firms in many countries have moved toward establishing collaborative marketing ventures in the supply chain. This phenomenon has driven the evolution of the chain and encouraged greater vertical and horizontal coordination. Horizontal coordination refers to alliances within a single part or level of a supply chain (e.g. farmer to farmer). Meanwhile, vertical coordination refers to the collaboration that occurs between parts or levels of the supply chain (e.g. retailers with processors with farmers) [48]-[50].

Particularly within the agricultural industry, horizontal coordination has existed for ages in the form of farmer cooperatives. Such horizontal alliances generally have three key driving factors: (1) to meet the volume requirements of most customers and increase bargaining power in their business; (2) to accelerate the pace and reduce the cost of penetrating new markets; and (3) to share the costs associated with new product development and creating or adopting innovation [48].

However, vertical coordination, which eventually leads to collaborative supply chain management, is very much a more current phenomenon. Vertical coordination can be defined as some arrangement between two or more exchange partners that is entered into freely so as to facilitate a mutual exchange that create satisfaction over time, and which leaves the operation and control of each business independent substantially [48], [49]. Vertical coordination is also defined as the means by which products are transported from the producer to the end consumer through the supply chain. The main driving factor of closer vertical coordination is the declining use of spot markets, whereas production and marketing contracts, strategic alliances, franchising, joint ventures, and full business integration are increasing. Changing consumer preferences, information technology, biotechnology, environmental pressures, credit and risk issues, and the free trade which reduce global exchange barriers are also some of the driving forces of increasing vertical coordination. Because these factors often result in relatively higher transaction costs for the traditional spot market transactions, closer vertical coordination takes place [51].

To some extent, government (public) policies also have a significant role to play in the integration of supply chains (in particular, the food supply chains). In the agricultural food sector, queries over the implications of government policy to closer vertical coordination have existed in the US since seventy years ago, when changing technology, production risks and the price were influential in driving some US agricultural sectors, such as broilers, towards closer and contracting vertical integration. While the economic rationale behind various aspects of the traditional role of government policy in the agricultural industry and market development has been to reduce information asymmetry and to correct market failure, government policy in fact often creates new problems or unpredictable outcomes due to improper implementation or unfavourable conditions. Further attention is therefore needed in the area of the role of public policy in facilitating or impeding the requirements of relationships [52].

Especially in developing countries, in order to survive in this highly competitive environment, agribusiness companies together with policy makers and development agencies must respond to the challenges, so that:

- producers, processors, and marketers are able to respond dynamically to changing consumer demands, both in local markets and in international markets;

- production processes are organised in such a way that added value could be maximised in order to strengthen both the international competitive position of the companies involved and the economic structure of the country; 
- smallholders and the poor can be integrated into the emerging value chains and benefit from the increased value generated by these chains; and

- farmers, as the ultimate producers, can obtain benefit from the applications of refined logistics management that continuously improve the pace of product movement through distribution channels as customers look to get the right volume and more precise mix of products in the channels [53].

This concept is important as vertical supply chain coordination often does not occur by itself. It requires commitment and the effort of all chain participants and stakeholders, also support from the government. Particularly in emerging economies, the role of public support in the development of supply chains is predominantly important.

While contemporary agri-food supply chain tends to involve a complicated but flexible process, the globalization processes of the agribusiness supply chain, changing the connectivity mode between food production and consumption requires linking the food to the social, cultural and environment contexts within which it is produced and distributed. From a global perspective, the prospective of the managing value chain has become a central focus of many recent international agricultural development strategies [54].

\section{TOWARDS THE NEW CONCEPT OF FOOD SECURITY POLICY}

Food security is an intrinsically unobservable concept. The term has largely eluded precise and operational, but contextual definition. Recent definitions of food security have tended to focus more on individuals' access to food not only quantitatively adequate but also nutritionally adequate. The concept also has several differing dimensions, all of which have a variety of consequences. For example, commonly 'food security' is defined as a situation in which whole people always have not only physical but also economic access to enough food. Food security exits when all people meet their dietary needs for a healthy and productive life [2], [55]-[58]. Implicit in this definition are the following three dimensions of food security: availability; stability; and access. Food availability means that, on average, available food supplies are adequate, in terms of both quantity and quality, to meet consumption requirements. Stability refers to minimising the possibility of the level of food consumption falling below those requirements due to seasonal variations or other difficult circumstances. Finally, access draws attention to the fact that even in a bountiful supply situation, many people are still hungry because they do not have access to the resources to produce or purchase the food they need.

Food security is clearly a public domain. Food security is an essential feature of a country's food sustenance and independence. However, food security is also a highly emotive issue, as chronic hunger, local food shortages, and sudden increases in food prices can strongly influence public sentiment and reaction. Thus, while the public's view of food security can be somewhat vague it still operates as an emotionally powerful concept with regard to what the public expects in this regard. Therefore, the ability to provide assurance that on a long-term basis food systems can provide all people with access to a reliable, timely and adequate supply of nutritious food is the responsibility of every government in the world [59].

\subsection{The Evolution of Thinking about Food Security}

The concept of food security first appeared in the late 1960s from international development work. In this pivotal work, food security was initially defined as the ability of households to meet whole dietary needs regularly [60]. However, over the past thirty years, thinking about food security has advanced from this narrow focus on the ability to deliver aggregate food requirements towards a broader framework of individual manners in the face of irreversibility, uncertainty and binding constraints on food selection [56].

There are five distinct stages in the evolution of our thinking and practice around food security [61]. The first stage occurred in the period of the 1970s and was characterised by the inadequacy of food supplies at global and national levels. The World Food Conference held in 1974 was designed to highlight this focus. The second stage occurred during the period of Sen's seminal work on poverty and famines [62], which was characterised by severe food crises in Africa in spite of the substantial expansion in food supplies at the global and national levels that had occurred in the 1970s. The third stage occurred in the period when food supply was recognised as a succinct element in determining nutritional security. Related food security concerns, such as the environment, culture, local practices, education, and health, started to come into consideration as the means for combating food insecurity. The fourth stage sought to locate not only food but also nutritional security within an array of goals that poor households pursue survival. A greater understanding of the connections between the political and economic aspects of hunger and malnutrition related to poverty, and the dynamic complex strategies that poor households engage to secure their survival were exposed. Finally, the fifth stage relates to the contemporary desire to extend the food or household security model by emphasising adequate nutrition all through the life cycle.

From a broader perspective, the evolution of thinking of food security since the World Food Conference in 1974 can be depicted into three key paradigm shifts, namely: (1) from global or national concern towards household or individual; (2) from a food first perspective towards a livelihood perspective; and (3) from objective measurements towards more subjective perception [2].

The first paradigm shift can be seen from the transformation of the food security concept. Its definition demonstrates that the food security concept has moved from the macro perspective towards the micro and 
individual perspective. In 1974, the definition developed at the World Food Conference still emphasised producing enough food to meet world requirements, making sure that this supply was reliable to avoid dramatic price fluctuations. These concerns logically led to the creation of new institutions to improve national food self sufficiency. Meanwhile, recent research has tended to favour the view that access to food by individuals is pervasively linked to the control they have over resources and the level of access they have over family income [2], [63], [64]. The second paradigm shift reflects a shift away from a narrow 'food first' approach to a wider and more sustainable livelihood approach. This is reflected by the transformation of objectives, priorities, time preferences, entitlement, the concept of security, and relationship to the environment. The consequence of this idea is a view of food security which recognises livelihood as a necessary condition of food security [2], [64]. This shift also involved two important changes in how food security was viewed. First, that it was dependent on individuals and households having a reliable source of livelihood, and second, that however defined, it required a longer timeframe or planning horizon than "immediate" [63]. The third paradigm shift reflects a move away from an objective approach to a subjective approach. Conservative approaches have traditionally relied on numeric target levels of consumption, such as average required daily calorie intake, for example. However, the idea underpinning more recent approaches is more subjective in nature. The implication of this idea is that nutritional quantity is a necessary but not sufficient condition for food security. Consequently, it is not only the quantity of food that matters but also its quality [2], [64].

\subsection{Food Security and Price Stabilisation Policy}

To achieve food security, government in developing economies traditionally apply price stabilisation policy to ensure that the price of a staple food, e.g., rice in one hand, should be affordable for consumers while on the other hand, the price of paddy should be high enough to give incentive for farmers as rice producers to grow rice. However, there has been a prolonged debate on whether the price stabilisation policy is beneficial or detrimental for the economy. On the one hand, scholars who believe in the traditional micro-level welfare analysis of price stabilisation find the benefits arising from price stabilisation tend to be insignificant unless consumers and producers attach great importance to risk aversion. However, the macroeconomic benefits of price stability are completely ignored within such an analysis [65].

On the other hand, Timmer and his colleagues have dealt with the production, marketing and consumption of what they have termed as macro food policy, and believe that government intervention to stabilise domestic prices for staple foods, especially rice, is in fact feasible in the context of expanding economic growth and the functioning of the private marketing sector. Conceptual arguments justifying this position emphasise the rationale that for countries where the majority of consumers are still poor (e.g. some developing countries in East and South East Asia), price stabilisation policy has been found to be very helpful in reducing people's exposure to food insecurity. Moreover, with the dominance of rice in their diets coupled with the extremely unstable rice price in the world market, it can be argued that if food price is unstable and thus, food security is questionable, political stability and economic growth will also be threatened [59], [66], [67].

The most common stabilisation scheme in developing economies is a buffer stock management controlled by the government, or a combination of trade policies and buffer stock system. If prices are set within a band, the government commonly sets what is known as a floor price and a ceiling price. The floor price, protecting farmers, is the minimum price below which grain prices will not be permitted to drop. The ceiling price, which protects consumers, is the maximum price, above which rice prices will not be permitted to rise. A public agency generally purchases farmers' grains to be kept as buffer stock if prices at the farm gate fall below the floor price. Conversely, the public agency will release the buffer stock if grain prices at the consumer level reach the ceiling price [65].

Scepticism with regard to the effectiveness of this common type of food policy generally suggests that government intervention in price stabilisation is often costly thus rarely possible, especially for long periods of time. Some critics also consider that the social benefits arising from stabilised prices are small or even negative [68], [69]. Political economists argue that institutional costs, that are incurred in price stabilisation policy are also much higher than even the potentially large benefits derived from price stability [70], [71].

While such stabilisation schemes have been found to be successful in stabilising the average national prices in some Asian countries, national price stabilisation schemes are expensive and frequently not effective in stabilising prices in rural areas. Thus, alternative policies for decreasing local price instability need to be considered [72]. They further believe that the elimination of destabilising government distortions is the most costeffective method for increasing price stability. Government efforts thus should be directed to facilitating private markets through improving infrastructures, enforcing measures and standards, and implementing small scale storage technology.

Furthermore, since public sector agencies are often too slow to respond to market situation changes, private sector businesses should be encouraged to operate in domestic and foreign markets. As private traders learn to function, over time public stocks or trade can be reduced gradually. While the need for public stocks cannot be totally eliminated by reliance on trade policy and private traders, the increasing role of the private sector is expected to minimise excessive stock procurement by government and unnecessary losses [65]. Encouraging the role of the private sector is critically important as the budgetary implications of price stabilisation and buffer stock policies become increasingly burdensome. Further to this, it is argued that 
the focus on price support is no longer appropriate for coping with an ever increasing number and complexity of domestic and international policy, e.g. WTO obligations [73].

\subsection{Food Security: Needs for Policy Shifts}

Along with the growing recognition that traditional agricultural policies are to some extent failing to achieve their objectives, there are also emerging ideas that globalisation and the changing character of the food system have shaped the need for policy shifts. One of the major factors triggering the emergence of these ideas is that in a more competitive environment, the food system should be efficient. As Maxwell argues:

"... all stages in the food chain, from production to final consumption, should be efficient in a social-welfare sense. Production policies should take account of dynamic comparative advantage; marketing margins should provide no more than normal profits in the long term; and consumer prices should reflect real scarcity values" $[74$, p. 16].

In addition, beyond efficiency, the new evaluation framework should also incorporate sustainability and impact. Sustainability emerges as the other key issue for consideration, and in this regard concerns have multiplied around increasing 'green' technology and developing long term solutions to promote both environmental sustainability and competitive advantage The impact of the food system is probably best approached of welfare, and valuable lessons learnt from the poverty literature. For example, income is no longer considered a single dimension but incorporates a range of more complex dimensions such as stability, equity and gender equality [75].

While to some extent developing countries have tried to reform their agricultural policies, many have been confronted with great difficulties and the progress towards effective, efficient, and competitive private markets is relatively slow. Reasons for this narrow success include: (a) the institutional inadequacies and structural weaknesses of domestic markets; (b) a lack of commitment and strong scepticism on the part of national or local government; (c) weaknesses in the planning and implementation of reform programs; and (d) a lack of trust by private sectors in the level of commitment of policy makers to market reform. As such, these constraints are often intangible and difficult to control during the reform process. The ultimate challenge perhaps is to find a suitable balance between the facilitation of private sector participation with the complementary roles the government needs to play in reducing transaction costs, promoting effective competition, and easing the transition for low income producers, especially growers and consumers [76]. This implies that government needs to formulate better strategies and more effective policy so that competitive advantage of the food system (industry) can be enhanced.

Traditionally, especially with staple food, most countries tend to use the food self-sufficiency approach which endorses the country to meet its food demands or a substantial part of it from domestic production rather than adopt a more risky self-reliance approach in which a country pursues an externally oriented trade regime with a view to earning enough from its exports of more competitive products to finance its food demands [77]. Under this self-sufficiency approach, government tends to protect their staple food industry by maintaining competitiveness of domestic production through the use of policy instruments, such as input subsidy, price policy, import tariff and quota [78]-[80]. Such policy, however, is increasingly criticized as arguably it does not reflect the 'real' comparative (and competitive) advantage of the countries. Such policy potentially distorts market. Whereas, particularly under the spirit of trade liberalization, countries are encouraged to gradually reduce the use of unfair trade policy and practices while improving their true competitive advantage which reflects fair competition and creates more efficient economy [81].

In this regard, policy shifts are needed. For effective food security policy, every national government needs to change its policy orientation from merely protecting its food industry towards developing 'true' competitive advantage so that allocation of resources should in time reflect optimal outcomes [82]. Competitive advantage strategies are indeed required to ensure efficiency in supply, both quantity and quality, so that the industry can effectively compete with imports. It thus helps to maintain and even further encourage domestic production which results in improving level of self-sufficiency [83]. More importantly, improved competitive advantage in the food industry can develop more sustained food security through enhancing chain members' income which results in improved purchasing power and thus their access to better quality of food in turn.

\section{LINKING SUPPLY CHAIN MANAGEMENT AND FOOD SECURITY POLICY}

Overall, a review of the literature on food security has provided the following understandings:

a. The food security concept has advanced over time. However, the basic dimensions of food security are availability, stability which are related to food supply and access.

b. The thinking about food security has advanced from a focus on aggregate food availability towards a broader framework of individual behaviour encompassing a livelihood perspective.

c. A country generally requires establishing an integrated policy to ensure that all populations always have access physically and economically to sufficient food to meet their dietary needs, Developing countries in East and South East Asia commonly use price stabilisation policy as the main instrument for maintaining consumers' purchasing power and the farm gate price. 
However, this kind of policy has been widely criticised, as it is frequently ineffective and is very costly to implement.

d. Along with the growing recognition of traditional policy ineffectiveness, globalisation and the changing character of the food system have also shaped the need for policy shifts. One of the major factors triggering the emergence of these ideas is that in a more competitive environment, the food system should be efficient and competitive.

What does the review of literature in supply chain management can bring to this conceptual framework?

a. Supply chain management is an integrated approach to creating value and competitive advantage. Supply chain management benefits all participants in the chain as it seeks to break down the barriers which exist between each of the links in the chain, in order to achieve better efficiency and competitive advantage. The supply chain management philosophy has broadened the concept of partnerships into a multi-firm's efforts to better manage the overall flow of goods from the supplier to the ultimate customer.

b. From a food policy point of view, on the one hand, government (public) policies may have a significant role to play in the formation of collaborative supply chains. On the other hand, supply chain management may help to manage long lasting partnerships and collaboration between small firms and large enterprises, and also between the private sector and the public sector. With collaboration and partnership, supply chain management may also help industry to be able to respond dynamically to changing consumer demands, both in local markets and in international markets.

c. Through better logistics management, information management and relationship management, supply chain collaboration can improve the efficiency of firms across the chain. More importantly, supply chain management allows more equitable value sharing among participants in a supply chain.

d. If the number of firms involved in the supply chain collaboration is increasing, the national competitiveness of the industry will also increase. This is the context in which the future of food policy should be developed.

Figure 1 describes the links that can be established between the concept of supply chain management and food security policy. It shows that building a competitive advantage of individual firms and their respective supply chains is the key factor linking SCM and Food Security Policy.

The use of the supply chain management concept to improve the food security of a country is arguably feasible since: (1) supply chain management can increase the competitiveness of private firms within the agribusiness system, e.g. rice industry, whereby the national competitive advantage of the rice supply chain as a system can be enhanced; (2) the basic concept of supply chain management (i.e. improving efficiency by reducing costs, sharing risks, managing relationships and enhancing value creation) is a universal concept that can be applied not only to private sectors but also to the public sector; and (3) on a more practical level, the desired outcomes of food security policy (i.e. availability, stability and access) can be achieved through applying the concept of supply chain management, as it encourages firms to work collaboratively with more equitable value sharing. This situation will be beneficial not only to large private firms, but more importantly will also be beneficial to smallholders, including small farmers as their inclusion will be considered as the determinant of the more sustainable supply system.

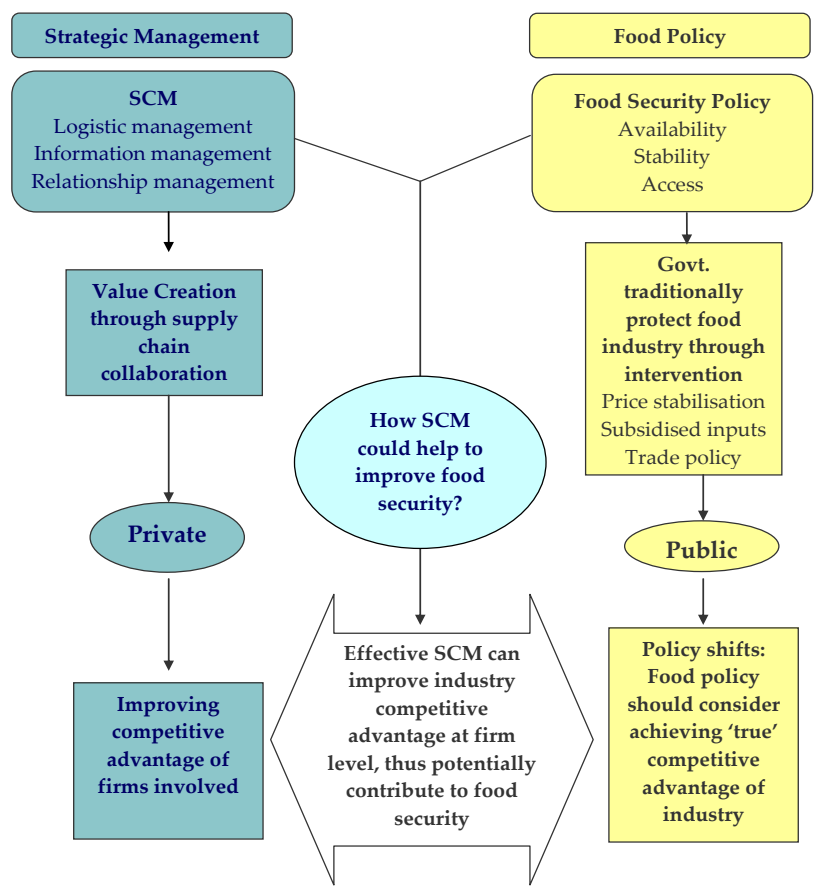

Figure 1. Linking SCM and Food Security Policy

Empirically, the potential of implementing supply chain management concept to improve the food security has been observed in Indonesia, where there is an evidence that the principles of supply chain management have been partly implemented, especially in the modern rice supply chain, where product differentiation is applied and thus availability and offer quality of the product is prominent [84].

Furthermore, increasing relevance and impact of agri-food SCM and it's interplay together with the advancements and applications of agribiotechnology is also found to have positive implications on food security and growth in Malaysia[85].

\section{CONCLUDING REMARKS}

Overall, this review of literature suggests that: 
a. The key words for the future development of food policy in general and food security in particular are efficiency and competitive advantage. An effective and efficient food security policy, therefore, need to consider achieving a competitive advantage as one of its goals.

b. Based on these key words, it can be argued that supply chain management is a useful concept for guiding the development of food security policy towards achieving efficiency and competitive advantage, as it is an integrated approach to creating value and competitiveness.

c. Particularly in developing countries, where government support for the development of supply chain management is still limited, linking the ways in which food security can be supported by supply chain management will help to identify more integrative policy approaches.

\section{REFERENCES}

[1] United Nations, "Report of the world food conference," New York, 1975.

[2] S. Maxwell, "Food security: a post-modern perspective," Food Policy, vol. 21, no. 2, pp. 155-170, 1996.

[3] R. Campbell et al., "Global food security response: West Africa rice value chain analysis," USAID, 2009

[4] J. F. Cox, J. H. Blackstone, and M. S. Spencer, APICS Dictionary. Falls Church, VA: American Production and Inventory Control Society, 1995.

[5] M. Christopher, Logistics and supply chain management. London; New York: Pitman Publishing, 1992.

[6] J. C. Johnson and D. F. Wood, Contemporary physical distribution and logistics, 3rd ed. New York: Macmillan; Collier Macmillan, 1986.

[7] P. J. Metz, "Demystifying supply chain management," Supply Chain Manag. Rev., vol. 1, no. 4, pp. 46-65, 1998.

[8] M. D. Boehlje, S. L. Hofing, and R. C. Schroeder, "Value chain in agricultural industries," Departement of Agricultural Economics Purdue University, Ag. Education and Consulting, LLC, 1999.

[9] M. D. Boehlje, "Structural changes in the agricultural industries: how do we measure, analyze and understand them?," Am. J. Agric. Econ., vol. 8, no. 1, pp. 1028-1041, 1999.

[10] M. C. Cooper and L. M. Ellram, "Characteristics of supply chain management and the implications for purchasing and logistics strategy," Int. J. Logist. Manag., vol. 4, no. 2, pp. 1-10, 1993.

[11] G. C. Stevens, "Integrating the supply chains," Int. J. Phys. Distrib. Mater. Manag., vol. 8, no. 8, pp. 3-8, 1989.

[12] B. J. La Londe and J. M. Masters, "Emerging logistics strategies: blueprints for the next century," Int. J. Phys. Distrib. Logist. Manag., vol. 24, no. 7, pp. 35-47, 1994.

[13] L. M. Ellram and M. C. Cooper, "Supply chain management, partnership, and the shipper-third party relationship," Int. J. Logist. Manag., vol. 1, no. 2, pp. 1-9, 1990.

[14] J. T. Mentzer et al., "Defining supply chain management," J. Bus. Logist., vol. 22, no. 2, pp. 1-25, 2001.

[15] D. F. Ross, Competing through supply chain management: creating market-winning strategies through supply chain partnerships. Dordrecht: Kluwer Academic, 1998.

[16] A. Fearne, “'Editorial note', supply chain management," Supply Chain Manag., vol. 1, pp. 3-4, 1996.

[17] A. V Iyer and M. E. Bergen, "Quick response in manufacturer-retailer channels," Manage. Sci., vol. 43, no. 4, pp. 559-570, 1997.

[18] D. M. Lambert and M. C. Cooper, "Issues in supply chain management," Ind. Mark. Manag., vol. 29 , pp. 65-83, 2000.

[19] R. J. Collins, "The 'locus of value' a hallmark of the chains that learn," Supply Chain Manag. An Int. J., vol. 7, no. 2, pp. 318-321, 2002.

[20] R. M. Morgan and S. D. Hunt, "The commitment-trust theory of relationship marketing," J. Mark., vol. 58, no. 3, pp. 20-38, 1994.

[21] E. Gummesson, "Making relationship marketing operational," J. Mark. Manag., vol. 5, no. 5, pp. 1-20, 1994.

[22] E. Gummesson, "In search of market equilibrium: relationship marketing versus hypercompetition," J. Mark. Manag., vol. 13, no. 5, pp. 407-419, 1997.

[23] L.-G. Mattsson, "Relationship marketing and the markets-as-networks approach: a comparative analysis of two evolving streams of research.," $J$. Mark. Manag., vol. 13, no. 5, pp. 447-461, 1997.

[24] L. L. Berry, "Relationship marketing of services - growing interest, emerging perspectives," $J$. Acad. Mark. Sci., vol. 23 (Fall), pp. 236-245, 1995.

[25] J. Arndt, "Toward a concept of domesticated market," J. Mark., vol. 43, no. 4, pp. 69-75, 1979.

[26] H. Hakansson, International marketing and purchasing of industrial goods : an interaction approach. Chichester; New York: Wiley, 1982.

[27] S. L. Han, D. T. Wilson, and S. P. Dant, "Buyersupplier relationships today," Ind. Mark. Manag., vol. 22, no. 4, pp. 331-338, 1993.

[28] R. Loader, "Assessing transaction costs to describe supply chain relationships in agri-food systems," Supply Chain Manag., vol. 2, no. 1, pp. 23-35, 1997.

[29] R. S. Achrol, "Changes in the theory of interorganisational relation in marketing: toward a network paradigm," J. Acad. Mark. Sci., vol. 25, no. 1, pp. 56-71, 1997.

[30] S. Ganesan, "Determinants of long-term 
orientation in buyer seller relationships," $J$.

Mark., vol. 58, no. 2, pp. 1-19, 1994.

[31] D. T. Wilson, "An integrated model of buyerseller relationships," J. Acad. Mark. Sci., vol. 23, no. 4, pp. 335-345, 1995.

[32] C. Moorman, R. Deshpande, and G. Zaltman, "Factors affecting trust in market research relationships," J. Mark., vol. 57, no. 1, pp. 81101, 1993.

[33] E. Anderson and B. A. Weitz, "Determinant of continuity in conventional industrial channel dyads," Mark. Sci., vol. 8, no. 4, pp. 310-323, 1989.

[34] J. C. Anderson and J. A. Narus, "A Model of distributor firm and manufacturer firm working partnerships," J. Mark., vol. 54, no. 1, pp. 42-58, 1990.

[35] P. J. Batt and N. Rexha, "Building trust in agribusiness supply chains: a conceptual model of buyer-seller relationships in the seed potato industry in Asia," J. Int. Food Agribus. Mark., vol. 11, no. 1, pp. 1-17, 1999.

[36] F. R. Dwyer, P. H. Schurr, and S. Oh, "Developing buyer-seller relationships," $J$. Mark., vol. 51, no. 2, pp. 11-27, 1987.

[37] C. Moorman, G. Zaltman, and R. Deshpandhe, "Relationships between provider and users of market research: the dynamics of trust within and between organisation," J. Mark. Res., vol. 29, no. 3, pp. 314-328, 1992.

[38] G. T. Gundlach, R. S. Achrol, and J. T. Mentzer, "The structure of commitment in exchange," $J$. Mark., vol. 59, no. 2, pp. 78-92, 1995.

[39] P. J. Batt, "Incorporating measures of satisfaction, trust and power-dependence into an analysis of agribusiness supply chains," Agriproduct supply chain management in developing countries. ACIAR, Denpasar, Bali, 2004.

[40] J. J. Cadilhon, A. Fearne, P. T. Giac Tam, P. Moustier, and N. D. Poole, "Quality incentives and dependence in vegetable supply chains to Ho Chi Minh City," Acta Hortic., vol. 699, pp. 111117, 2006.

[41] A. Cox, "Managing with power: strategies for improving value appropriation from supply relationships," J. Supply Chain Manag., vol. 37, no. 2, pp. 42-47, 2001.

[42] A. Cox, "The power perspective in procurement and supply management," J. Supply Chain Manag., vol. 37, no. 2, pp. 4-7, 2001.

[43] M. K. Hingley, "Power imbalance in UK agrifood supply channels: learning to live with supermarkets?," J. Mark. Manag., vol. 21, pp. 63-88, 2005.

[44] R. M. Emerson, "Power-dependence relations," Am. Sociol. Rev. , vol. 27, pp. 31-41, 1962.

[45] M. E. Porter, Competitive advantage : creating and sustaining superior performance. New York: Free Press ; London : Collier Macmillan, 1985.

[46] M. O'Keefe, "Supply chain management,"
Agric. Sci., vol. 10, no. 3, pp. 29-32, 1997.

[47] J. Hamprecht and D. Corsten, "Controlling the sustainability of food supply chains," Supply Chain Manag. An Int. J., vol. 10, no. 1, pp. 7-10, 2005.

[48] A. Fearne, "The evolution of partnerships in the meat supply chain: insights from the British beef industry," Supply Chain Manag., vol. 3, no. 4, pp. 214-231, 1998.

[49] D. R. Hughes, Breaking with tradition : building partnerships \& alliances in the European food industry. Ashford, Kent, UK: Wye College Press for the Food Industry Management Group, Wye College, 1994.

[50] G. Thompson, "Supply chain management: building partnerships and alliances in international food and agribusiness," Rural Industries Research and Development Corporation (RIRDC), Barton, 2001.

[51] L. M. Young and J. E. Hobbs, "Vertical linkages in agri-food supply chains: changing roles for producers, commodity groups, and government policy," Rev. Agric. Econ., vol. 24, no. 2, pp. 428-441, 2002.

[52] L. M. Young and J. E. Hobbs, "Public policy responses to increased vertical linkages in agrifood supply chains," in The Joint Meetings of Canadian Agricultural Economics Society and Canadian Economics Association, 2000.

[53] J. Van Roekel, R. Kopicki, C. J. E. Broekmans, and D. M. Boselie, "Building agri supply chains: issues and guidelines," World Bank Paper Cross-Border Agri Supply Chain Management, 2000.

[54] F. Zecca and N. Rastorgueva, "Supply Chain Management and Sustainability in Agri-Food System: Italian Evidence," J. Nutr. Ecol. Food Res., vol. 2, no. 1, pp. 20-28, 2014.

[55] B. Arifin, A. Munir, E. S. Hartati, and D. J. Rachbini, "Food security and markets in Indonesia: state-private interaction in rice trade," South Asia Council for Food Security and Fair Trade, Kuala Lumpur, 2001.

[56] C. B. Barret, "Food security and food assistance program," in Handbook of agricultural economics, vol. 2, B. L. Gardner and G. C. R., Eds. Amsterdam; New York: Elsevier Science, 2002.

[57] FAO, "Rome Declaration on World Food Security and World Food Summit Plan of Action." Rome, 1996.

[58] C. P. Timmer, "Food security and economic growth: an Asian perspective," Asia. Pac. Econ. Lit., vol. 19, no. 1-17, 2005.

[59] C. P. Timmer, "Food security in Indonesia: current challenges and the long-run outlook," no. 48, Washington D. C., USA: Center for Global Development, 2004.

[60] J. Von Braun, H. Bouis, S. Kumar, and R. Pandya-Lorch, Improving food security of the poor: concept, policy, and programs. Washington D. C.: International Food Policy 
Research Institute (IFRI), 1992.

[61] C. G. Davis, C. Y. Thomas, and W. A. Amponsah, "Globalization and poverty: Lessons from the theory and practice of food security," Am. J. Agric. Econ., vol. 83, no. 3, pp. 714-721, 2001.

[62] A. K. Sen, Poverty and famines : an essay on entitlement and deprivation. Oxford: Clarendon Press ; New York : Oxford University Press, 1981.

[63] M. D. Anderson and J. T. Cook, "Community food security: Practice in need of theory?," Agric. Human Values, vol. 16, pp. 141-150, 1999.

[64] S. Maxwell, "The evolution of thinking about food security," in Food Security in Sub Saharan Africa, S. Devereux and S. Maxwell, Eds. Pietermaritzburg: University of Natal Press, 2001.

[65] N. Islam and S. Thomas, Foodgrain price stabilization in developing countries: issues and experiences in Asia, vol. 3. Washington, D.C.: International Food Policy Research Institute, 1996.

[66] C. P. Timmer, "Food price policy: the rationale for government intervention," Food Policy, vol. 14, pp. 17-27, 1989.

[67] C. P. Timmer and D. Dawe, "Managing food price instability in Asia:a macro food security serspective," Asian Econ. J., vol. 21, no. 1, pp. 1-18, 2007.

[68] J. R. Behrman, "Commodity price instability and economic goal attainment in developing countries," World Dev., vol. 15, no. 5, pp. 555573, 1987.

[69] M. Ravallion, Markets and famines. New York: Clarendon Press for Oxford University Press., 1987.

[70] O. Knudsen and J. Nash, "Domestic price stabilization schemes in developing countries," Econ. Dev. Cult. Change, vol. 38, pp. 539-557, 1990.

[71] M. Schiff and A. Valdes, "A synthesis of the economics in developing countries," in The Political Economy of Agricultural Pricing Policy, A. Valdes, Ed. Baltimore: The Johns Hopkins University Press, 1991.

[72] J. R. Anderson and J. A. Roumasset, "Food insecurity and stochastic aspects of poverty," Asian J. Agric. Econ., vol. 2, pp. 53-66, 1996.

[73] G. Viatte and J. Schmidhuber, "Long term policy issues and challanges for agro-food," in The future offood: long-term prospects for the agrofood sector, OECD, Ed. Paris: Organisation for Economic Co-operation and Development, 1998, p. 197 p.

[74] S. Maxwell, "National food security planning: first thought from Sudan," in To Cure All Hunger: Food Policy and Food Security in Sudan, S. Maxwell, Ed. London: Intermediate Technology Publications, 1991.

[75] S. Maxwell and R. Slater, "Food policy old and new," Dev. Policy Rev., vol. 21, no. 5-6, pp. 531-553, 2003.

[76] P. Pinstrup-Andersen, "Food policy research for developing countries: emerging issues and unfinished business," Food Policy, vol. 25, pp. 125-141, 2000.

[77] S. K. Gayi, "Does the WTO agreement on agriculture endanger food security in SubSaharan Africa?," in Food security indicators, measurement, and the impact of trade openness, B. Davis, Ed. New York: Oxford University Press, 2007, pp. 284-321.

[78] R. Chand, "International trade, food security, and the response to the WTO in South Asian Countries," in Food security indicators, measurement, and the impact of trade openness, B. Davis, Ed. New York: Oxford University Press, 2007, pp. 284-321.

[79] M. Herrmann, "Agricultural support measures of developed countries and food insecurity in developing countries," in Food security indicators, measurement, and the impact of trade openness, B. Davis, Ed. New York: Oxford University Press, 2007, pp. 284-321.

[80] E. A. Monke and S. R. Pearson, The policy analysis matrix for agricultural development. Ithaca, N.Y.: Cornell University Press, 1989.

[81] R. Farouquee and R. Ali, "Pakistan's public agricultural enterprises: Inefficiencies, market distortions, and proposal for reforms," Discussion Paper 305. World Bank, Washington, D.C., 1995.

[82] D. A. Summer, "Food security, trade and agricultural commodity policy," Symposium on Challenging the Agricultural Economics Paradigm. Columbus, OH., 2000.

[83] C. C. David, "Towards an efficient path to food security: the Philippine case," Discussion Paper, vol. 98-39. Philippine Institute for Development Studies, Makati City, 1998.

[84] J. M. M. Aji, "Improving food security through supply chain management: a study of rice supply chains in Indonesia," The University of Queensland, 2010.

[85] L. C. Y. Wong, "Food security and growth: Malaysia's strategic approach and future adjustment," in Food Security Malaysia, Kuala Lumpur: Academy of Science Malaysia Institute of Strategic and International Studies , 2009, pp. 55-67. 